\title{
Phytoplankton community distribution in relation to environmental parameters in three aquaculture systems in a Chinese subtropical eutrophic bay
}

\author{
Zhi-Bing Jiang ${ }^{1}$, Quan-Zhen Chen ${ }^{1}$, Jiang-Ning Zeng ${ }^{1, *}$, Yi-Bo Liao ${ }^{1}$, Lu Shou $^{1,2}$, \\ Jingjing Liu ${ }^{1}$
}

${ }^{1}$ Laboratory of Marine Ecosystem Biogeochemistry, Second Institute of Oceanography, SOA, Hangzhou 310012, PR China ${ }^{2}$ College of Life Sciences, Nanjing Normal University, Nanjing 210097, PR China

\begin{abstract}
There is concern about the impact of expanding coastal aquaculture activity, particularly in China, with the biggest aquaculture industry in the world. We conducted 3 cruises to the oyster, kelp and fish farms of the Xiangshan Bay during the winter-spring transition (02/2009), winter (01/2010) and spring (04/2010). Our aim was to explore the spatial heterogeneity of the phytoplankton community in different culture habitats and evaluate the effects of mariculture on phytoplankton. Different culture types formed unique small-scale habitats that exhibited various environmental gradients and forms of phytoplankton community patchiness. Both environmental (i.e. temperature, salinity, transparency, suspended solids, dissolved oxygen, $\mathrm{pH}$, dissolved inorganic nitrogen, $\mathrm{PO}_{4}-\mathrm{P}, \mathrm{SiO}_{3}-\mathrm{Si}, \mathrm{N} / \mathrm{P}$, and total organic carbon) and phytoplankton (i.e. cell density, chlorophyll $a$, species richness, main dominant species, and community structure) parameters were significantly different among the 3 culture habitats. Canonical correspondence analysis showed that phytoplankton distribution was mainly influenced by temperature, nutrition, salinity and suspended solids. Oyster and kelp farming effectively alleviated coastal eutrophication and also increased species richness and diversity; fish farming did not. Temperature elevation caused by the thermal discharge from a power plant induced phytoplankton blooms during the winter and winter-spring transition. Nevertheless, the filtering effect of suspended oysters dramatically reduced microalgal biomass. The kelp and oyster farms were much better than the fish farm in terms of water quality, phytoplankton composition, and habitat restoration function. These results provide guidelines for future policy-making in aquaculture as well as eutrophication control and management.
\end{abstract}

KEY WORDS: Xiangshan Bay · Aquaculture · Phytoplankton abundance · Community composition · Environmental parameters $\cdot$ Coastal eutrophication

\section{INTRODUCTION}

The mariculture of China has been steadily growing since the 1980s, when the transformation of traditional fishing began. This transformation has been brought about by the decline in fishery resources and capture in coastal areas. China currently has the largest aquaculture industry in the world, accounting for $67 \%$ of global production in terms of quantity and $49 \%$ of global value in 2006 (FAO 2009). In 2008, the annual production estimates of shellfish, fish, crustaceans, and seaweed were 10.08, $0.75,0.94$, and 1.39 million $\mathrm{t}$, respectively, with a total yield of 13.40 million $t$ (COYBEC 2009). Such a rapid development of mariculture provides abundant protein and contributes to the alleviation of food pressure in China caused by population increase. However, the disordered development and 
excessive exploitation of aquaculture also have negative environmental effects. In particular, fish and shrimp cultures require large energy inputs (Yang et al. 2004, Dong et al. 2008). The huge terrestrial nutrient input as well as the nitrogen $(\mathrm{N})$ and phosphorus (P) discharges from intensive mariculture activities lead to eutrophication in major Chinese coastal systems (Xiao et al. 2007), which can cause a succession of serious losses in the ecological, economic, and social benefits of coastal waters (see Bricker et al. 2008).

Marine phytoplankton play a key role in the food web. These organisms are crucial in the cycling of substances and energy in marine ecosystems. Once phytoplankton composition and production are altered by aquaculture effects (e.g. increased nutrients and variations in nutrient ratios), the biodiversity, ecological functions and biogeochemical cycling of culture areas also change (Souchu et al. 2001, Alongi et al. 2003). Fish cages and shrimp ponds release abundant organic and inorganic matter (i.e. $\mathrm{N}$ and $\mathrm{P}$ from unconsumed feed and fecal material that accumulate in water and sediments) resulting in eutrophication and phytoplankton blooms (Dong et al. 2008, Lauer et al. 2009). In contrast, macroalgal (seaweed) cultivation, as an environment-friendly aquaculture mode, can efficiently remove and assimilate $\mathrm{N}$ and $\mathrm{P}$, thereby alleviating the coastal eutrophication symptoms (Fei 2004, Neori et al. 2004, He et al. 2008). Consequently, macroalgae may compete with phytoplankton for inorganic nutrients and reduce the risk of algal bloom. Similarly, shellfish cultures (e.g. oyster, mussel and clam) exhibit strong top-down control of primary production by filtering large volumes of phytoplankton from the water column (Dupuy et al. 2000, Souchu et al. 2001, Huang et al. 2008, Lefebvre et al. 2009, Grangeré et al. 2010).

Given the significance of phytoplankton in culture regions, many researchers have recently paid attention to the effects of different culture types on marine phytoplankton. The types include fish cages (Alongi et al. 2003, Wang et al. 2006, Navarro et al. 2008, San Diego-McGlone et al. 2008, Sidik et al. 2008), suspended mussels (Trottet et al. 2008a,b, Huang et al. 2008), and shrimp ponds (Casé et al. 2008). However, the effects of macroalgal cultivation on phytoplankton have not yet been reported. The responses of phytoplankton assemblages to the various culture systems have also not been compared. The phytoplankton community structure and its relationship with environmental parameters under mariculture stress has not been explored either (Wang et al. 2006). All these phenomena need to be given attention.
Based on China's mariculture status, 3 typically cultured species (i.e. the Chinese oyster Ostrea plicatula, the kelp Laminaria japonica, and the Japanese seaperch Lateolabrax japonicus) were chosen to represent culture of suspended bivalves, macroalgae and fishes, respectively. The distribution pattern of the phytoplankton community and its relationship with environmental factors in the 3 above-mentioned culture systems in a subtropical eutrophical bay (Xiangshan Bay) in China were studied. The physical, chemical and biological parameters of the water column were investigated during different seasons. Aquaculture in this bay has expanded in the past 3 decades, evidence of the tremendously increased scale of mariculture in China (Ning \& $\mathrm{Hu} 2002$, Nobre et al. 2010). The objectives of the present study were (1) to explore the spatial distribution pattern of the phytoplankton community and examine its relationship with environmental parameters in different culture habitats of small scale, (2) to evaluate the effects of mariculture on phytoplankton and appraise superiority among them based on biological and chemical factors, and (3) to provide constructive guidelines for future aquaculture policymaking as well as eutrophication control and management.

\section{MATERIALS AND METHODS}

\section{Study area and sampling stations}

The Xiangshan Bay $\left(121^{\circ} 25^{\prime}\right.$ to $122^{\circ} 30^{\prime} \mathrm{E}, 2^{\circ} 9^{\circ} 5^{\prime}$ to $29^{\circ} 47^{\prime} \mathrm{N}_{\text {; }}$ see Fig. 1 ) is a large bay (tidal flat area: $198 \mathrm{~km}^{2}$; waters area: $365 \mathrm{~km}^{2}$ ) located in the Northern Zhejiang Province, China. This bay is long (ca. $60 \mathrm{~km}$ ), narrow, and connected to the East China Sea, with long residence times in the inner and middle sections (about 80 and $60 \mathrm{~d}$, respectively) for $90 \%$ water exchanges (Ning \& Hu 2002). The tidal current is dominated by a reciprocating flow with a range of $2.31 \mathrm{~m}$ in the study area. Residual circulation is mainly controlled by the gravitational circulation that arises from surface water flowing to the sea and bottom water flowing to the end of the fiord (Dong \& Su 2000a). Around the cultivated areas, the residual currents of the surface water during winter neap and spring tide are 2.86 and $5.82 \mathrm{~cm} \mathrm{~s}^{-1}$, respectively (Ning \& Hu 2002). Estimates of aquaculture production in the bay in 2005 to 2006 were $45000 \mathrm{t}$ shellfish $\mathrm{yr}^{-1}$ (93\% of which consists of the Chinese oyster produced either on ropes or in intertidal areas), $9400 \mathrm{t}$ finfish $\mathrm{yr}^{-1}$ (Nobre et al. 2010) and little kelp. 
Three cruises were conducted to the oyster (OP), kelp (LC) and fish (FC) farms in different seasons (Fig. 1, Table 1); the culture acreages of these farms were about 920, 20, and 18.7 ha, respectively (You \& Jiao 2011). Kelp is a cold water species cultivated only during the winter and spring seasons in Xiangshan Bay. Therefore, the surveys for the 3 culture systems were performed only during these 2 seasons. In each culture area, 3 or 4 sampling stations were set at the center (0) and edge (1), as well as at $100 \mathrm{~m} \mathrm{(2)} \mathrm{and}$ $1000 \mathrm{~m}$ (3) m away from the edge. Generally, most of the 2 to 3 yr old oysters are harvested in winter and spring. The young and juvenile animals are cultivated the following year. Kelp is usually harvested in late April, and our investigation date (25 April 2010) for the kelp farm was coincidentally within the harvesting period. The cultured fish were usually fed on mass trash fishes and some compound feeds in the morning. The samples were collected at noon.

\section{Environmental parameters}

Surface $(0.5 \mathrm{~m}$ depth $)$ and bottom $(0.5 \mathrm{~m}$ from the bottom) waters were collected at each station using a $10 \mathrm{l}$ plastic bucket. Water depth, transparency, $\mathrm{pH}$, temperature and salinity were monitored in situ. Water temperature and salinity were measured using a YSI model 30 salinity meter, and transparency was determined using a Secchi disc. Dissolved oxygen (DO) was measured by Winkler titrations, and $\mathrm{pH}$ was measured using an Orion 868 pH meter (Thermo Electron). For analysis of dissolved inorganic nitrogen (DIN: $\left.\mathrm{NO}_{3}-\mathrm{N}+\mathrm{NO}_{2}-\mathrm{N}+\mathrm{NH}_{3}-\mathrm{N}\right), \mathrm{PO}_{4}-\mathrm{P}, \mathrm{SiO}_{4}-\mathrm{Si}$, chlorophyll $a$ (chl a), total organic carbon (TOC), and suspended solids (SS), 51 water samples were kept in the dark and deep frozen before the laboratory procedures. The water samples were immediately filtered through pre-combusted (at $450^{\circ} \mathrm{C}$ for $4 \mathrm{~h}$ ) $0.45 \mu \mathrm{m}$ pore-size Whatman GF/F filters for nutrients and chl a. The nutrients were measured according to previously described colorimetric methods (Yin et al. 2001). Chl a

Table 1. Dates of sampling at 3 culture areas of Xiangshan Bay during different seasons. Dates are dd/mm/yy

\begin{tabular}{|lccc|}
\hline \multirow{2}{*}{ Season } & \multicolumn{3}{c|}{ Farm } \\
\cline { 2 - 4 } & Oyster & Kelp & Fish \\
\hline $\begin{array}{l}\text { Winter-spring } \\
\text { transition }\end{array}$ & $25 / 02 / 2009$ & $27 / 02 / 2009$ & $28 / 02 / 2009$ \\
Winter & $29 / 01 / 2010$ & $30 / 01 / 2010$ & $31 / 01 / 2010$ \\
Spring & $23 / 04 / 2010$ & $25 / 04 / 2010$ & $23 / 04 / 2010$ \\
\hline
\end{tabular}

was fluorescently determined using a Turner Designs 10-AU fluorometer. TOC was estimated by elemental analysis (Vario MICRO Cube, elemental analyzer). For SS analysis, after the samples were filtered through preweighed filters (Whatman GF/C), the filters were dried at $105^{\circ} \mathrm{C}$ to a constant mass and weighed. The dry mass of the particulate materials captured on each filter was calculated by subtracting the filter mass from the dried mass.

\section{Phytoplankton community}

Surface and bottom waters $(400$ to $500 \mathrm{ml}$ for each of the 3 samples) were poured into $500 \mathrm{ml}$ bottles at each station. All samples collected were stored with $4 \%$ formalin. After sedimentation (at least $48 \mathrm{~h}$ ), phytoplankton taxa were identified and counted on a scaled slide $(0.1 \mathrm{ml})$ under $200 \times$ or $400 \times$ magnification using a light microscope (Leica DM2500). At least 300 units (individual cells or colonies) were counted for each sample. The phytoplankton abundance was expressed as $\times 10^{4}$ cells $\mathrm{l}^{-1}$. Dominance $(D$ and $Y$ for certain stations and investigation regions, respectively) was calculated according to the following equations: $D=n_{i} / N_{i} Y=n_{i} f_{i} / N$, where $n_{i}$ is the number (cells) of individuals of species $i$ and $N$ is the total number of individuals, and $f_{i}$ is the frequency of species $i$ occurring in a sample. Only those species at certain stations that had a minimum of $2 \%$ contribution to the total abundance were considered to be dominants.

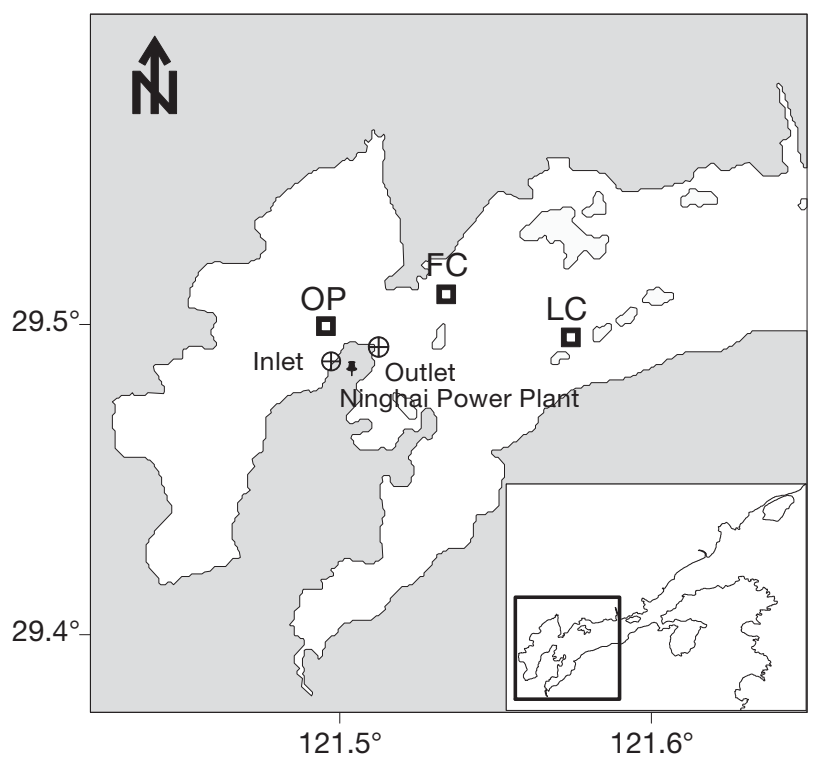

Fig. 1. The 3 sampled mariculture areas in the Xiangshan Bay. OP: oyster farm; FC: fish farm; LC: kelp farm 
Data analysis. The software SPSS 13.0 was used to analyse the data. Three-way (culture type, station and water layer) ANOVA was used to test for significant differences in the phytoplankton community and environmental variables. Prior to ANOVA, all variables were tested for normality (Kolmogorov-Smirnov test) and homogeneity (Levene test), and all were log transformed where necessary. Statistically significant differences $(p<0.05)$ among treatments were further assessed using the SNK test. Kruskal-Wallis $(H)$ test was performed on data that did not satisfy the assumptions of normality and homogeneity. If a significant difference was found on performing the $H$-test, a multi-comparison using the Nemenyi test was performed with the self-programming mode of the SPSS software.

Non-metric multidimensional scaling (NMDS) was performed to determine spatial patterns in community structure. Species abundances were transformed to the 4 th root before estimation using Bray-Curtis similarities between sample pairs. A 1-way analysis of similarity (ANOSIM) was used to test significant differences among the phytoplankton communities in the different culture systems. Otherwise, canonical correspondence analysis (CCA) was applied on $\log (x+1)$ transformed phytoplankton abundance and environmental data (except for the $\mathrm{pH}$ ). The purpose was to investigate the effects of environmental parameters on community structure (ter Braak \& Smilauer 2002). If $D$ of a species was less than 0.02 , the species was arbitrarily excluded from the CCA. The significance of environmental variables in explaning phytoplankton variance in a CCA was tested by Monte Carlo simulations with 499 unrestricted permutations. These analyses were performed using either CANOCO (v. 4.5) or PRIMER (v. 5.0) software packages.

\section{RESULTS}

\section{Environmental variables}

High levels of DIN (0.424 to $0.796 \mathrm{mg} \mathrm{l}^{-1}$ ), $\mathrm{PO}_{4}-\mathrm{P}$ (0.047 to $0.083 \mathrm{mg} \mathrm{l}^{-1}$ ), $\mathrm{SiO}_{3}$-Si (0.555 to $1.462 \mathrm{mg}$ $\mathrm{l}^{-1}$ ), and N/P (13.1 to 30.9) at oyster, kelp, and fish farms in different seasons was observed. This finding suggested a high eutrophic level and little P limitation of culture areas in the Xiangshan Bay (Table 2). ANOVA and Kruskal-Wallis tests revealed significant differences among environ-

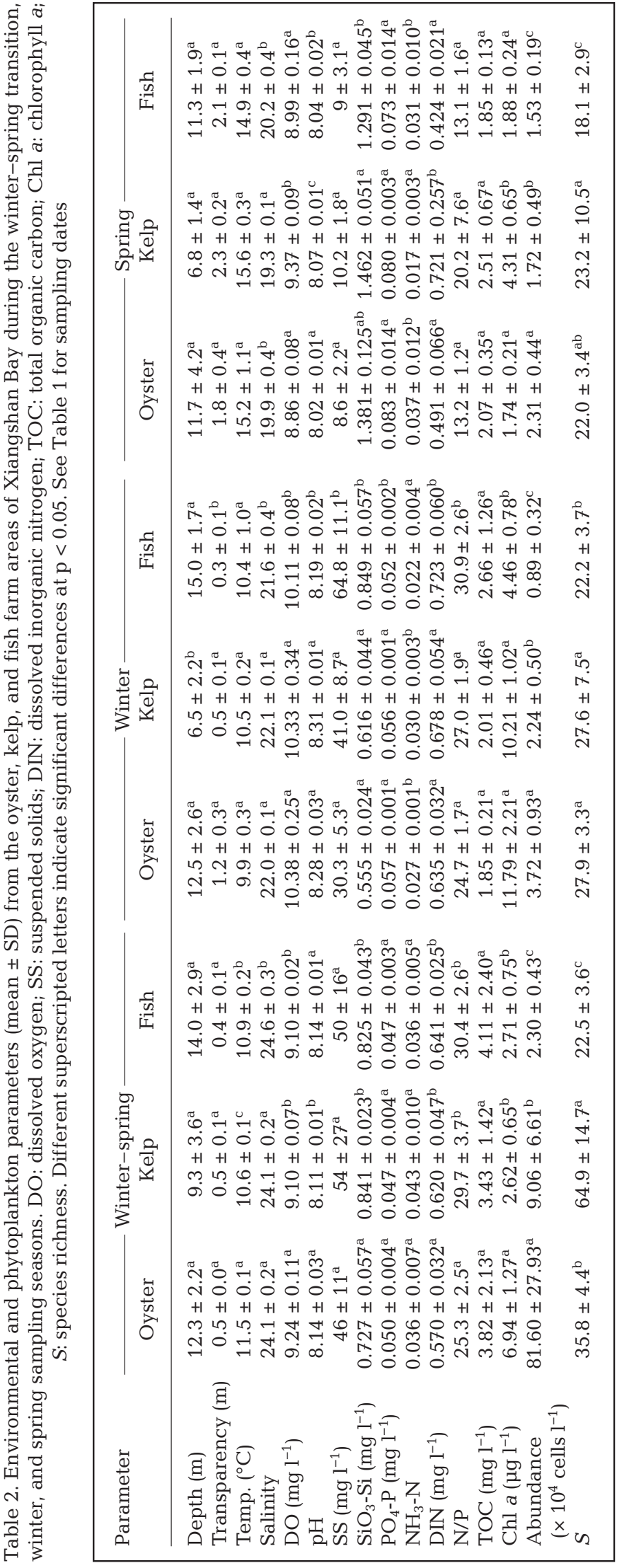



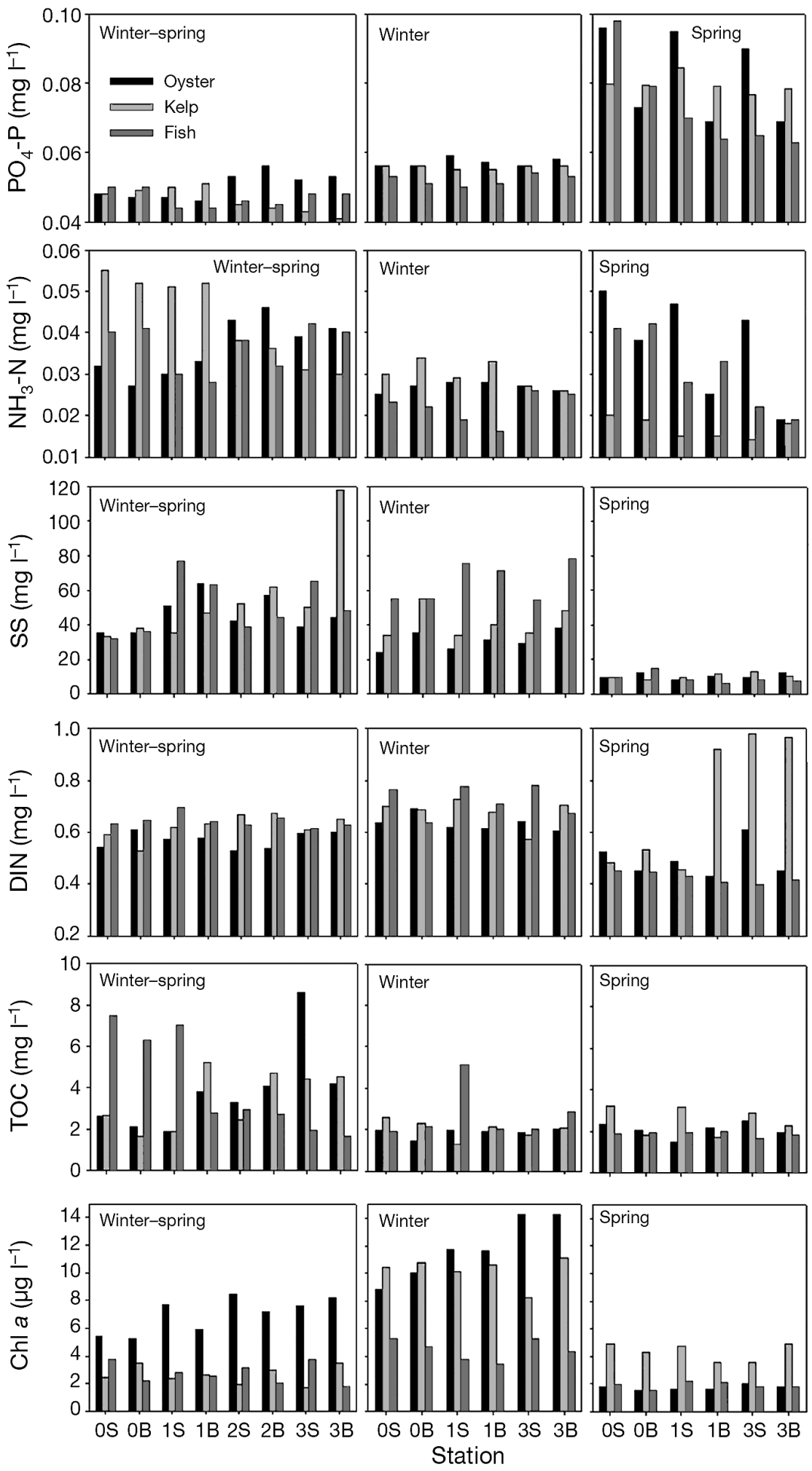

Fig. 2. Seasonal variation in environmental parameters and chlorophyll $a$ (chl a) concentration in surface (S) and bottom (B) waters at sampling stations located at the centre of culture areas (0), inside and at the edge (1), $100 \mathrm{~m}$ outside (2), and $1000 \mathrm{~m}$ outside (3). SS: suspended solids; DIN: dissolved inorganic nitrogen; TOC: total organic carbon; winter-spring transition: 02/2009; winter: 01/2010; spring: 04/2010 mental parameters (i.e. salinity, DO, $\mathrm{pH}, \mathrm{SiO}_{3}-\mathrm{Si}_{1} \mathrm{PO}_{4}-\mathrm{P}, \mathrm{DIN}$, and N/P) in the culture systems during all seasons. The levels of $\mathrm{SiO}_{3}-\mathrm{Si}, \mathrm{DIN}$, and N/P at the fish farm were higher than those at the oyster and kelp farms in winter and the winter-spring transition, but lower in spring. For the oyster farm (Fig. 2), the levels of surface DIN, TOC, and SS were higher outside than inside the farm; the bottom DIN values were higher than the surface ones; the levels of $\mathrm{PO}_{4}-\mathrm{P}$ and $\mathrm{NH}_{3}-\mathrm{N}$ at different stations had no specific trends. For the kelp farm (Fig. 2), both the surface and bottom levels of DIN, $\mathrm{PO}_{4}-\mathrm{P}$, and SS were generally lower inside than outside; surface $\mathrm{NH}_{3}-\mathrm{N}$ and TOC were higher inside than outside. For the fish farm in winter and winter-spring transition (Fig. 2), both surface and bottom levels of DIN, $\mathrm{NH}_{3}-\mathrm{N}, \mathrm{PO}_{4}-\mathrm{P}$, and TOC were a little higher inside than outside; in spring, the values were much higher inside than outside.

\section{Abundance and chl a}

The phytoplankton abundance at the kelp farm $(9.06,2.24$, and $1.72 \times$ $10^{4}$ cells l$^{-1}$ ) was lower than at the oyster farm $\left(81.60,3.72\right.$, and $2.31 \times 10^{4}$ cells $\mathrm{l}^{-1}$ ) but higher than at the fish farm $\left(2.30,0.89\right.$, and $1.53 \times 10^{4}$ cells $\mathrm{l}^{-1}$ ) in winter-spring, winter, and spring, respectively, (Table 2). The culture type had a highly significant $(p<0.001)$ influence on phytoplankton abundance in all seasons. The station and water layer had significant $(p<0.05)$ influences in winter and spring, but no impact in winter-spring (Table 3). There were highly significant differences between sampling stations at both oyster and kelp farms. Both the surface and bottom phytoplankton cell numbers inside (OP0 and OP1) the oyster farm were significantly $(\mathrm{p}<0.05)$ lower than outside (OP3) during all survey seasons (Fig. 3). Similar results were found for chl a (Fig. 2). The surface and bottom 
abundances at LC0 were significantly $(\mathrm{p}<0.05)$ higher than LC3 in winter and spring. Nevertheless, the surface cell density results in winter-spring were contradictory, and chl a inside the kelp farm was higher than outside. The surface and bottom phytoplankton cell numbers inside (FC0 and FC1) the fish farm were significantly $(p<0.05)$ lower than outside (FC3) in winter, but samples taken during other seasons showed no remarkable differences. Chl a at other stations also showed no difference.

Table 3. Three-way ANOVA $(F)$ and Kruskal-Wallis $(H)$ test results of abundance and species richness $(S)$ in culture areas of Xiangshan Bay during different seasons. ${ }^{\mathrm{NS}}$ : not significant, ${ }^{*} \mathrm{p}<0.05,{ }^{* *} \mathrm{p}<0.01,{ }^{* * *} \mathrm{p}<0.001$

\begin{tabular}{|ccccc|}
\hline Season & Parameters & Cultural type & Station & Water layer \\
\hline Winter- & Abundance & $H_{(2,72)}=59.6^{* * *}$ & $H_{(3,72)}=1.4^{\mathrm{NS}}$ & $H_{(1,72)}=1.1^{\mathrm{NS}}$ \\
spring & $S$ & $F_{(2,65)}=169.5^{* * *}$ & $F_{(3,65)}=3.0^{*}$ & $F_{(1,65)}=11.5^{* *}$ \\
Winter & Abundance & $F_{(2,48)}=135.3^{* * *}$ & $F_{(2,48)}=3.9^{*}$ & $F_{(1,48)}=22.3^{* * *}$ \\
& $S$ & $F_{(2,48)}=7.7^{* * *}$ & $F_{(2,48)}=3.9^{*}$ & $F_{(1,48)}=1.0^{\mathrm{NS}}$ \\
Spring & Abundance & $F_{(2,48)}=43.9^{* * *}$ & $F_{(2,48)}=6.2^{* *}$ & $F_{(1,48)}=8.7^{* *}$ \\
& $S$ & $F_{(2,48)}=4.9^{*}$ & $F_{(2,48)}=16.1^{* * *}$ & $F_{(1,48)}=3.1^{\mathrm{NS}}$ \\
\hline
\end{tabular}

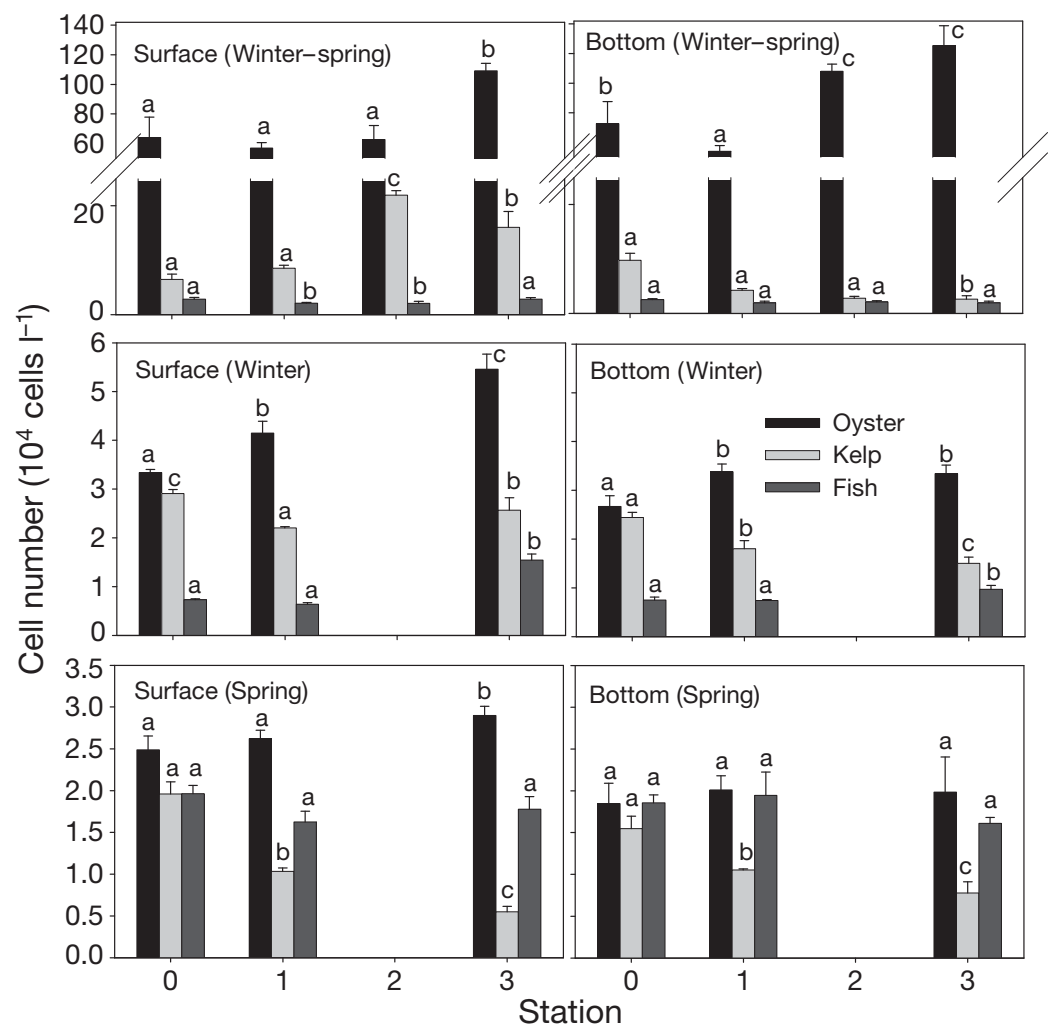

Fig. 3. Phytoplankton abundance at different sampling stations in 3 culture systems during the winter-spring transition, winter, and spring. Different lower-case letters show significant $(p<0.05)$ differences among stations (at the same farm and in the same water layer). See Fig. 2 for further details of stations and seasons

\section{Species richness $(S)$}

Phytoplankton $S$ was significantly $(\mathrm{p}<0.05)$ affected by the culture type and station in all survey seasons, but not by the water layer in winter and spring (Table 3). Phytoplankton $S$ at the oyster (35.8, 27.9, and 22.0) and kelp (64.9, 27.6, and 23.2) farms was significantly higher than at the fish farm $(22.5$, 22.2, and 18.1) in winter-spring, winter and spring, respectively. Both the surface and bottom $S$ inside the oyster and kelp farms were much higher than that outside during all survey seasons (Fig. 4). $S$ inside and outside the fish farm showed no obvious difference.

\section{Dominant species}

Table 4 reveals an obvious discrepancy among the phytoplankton dominant species compositions (or dominances) of the 3 culture areas in all survey seasons. For instance, during the winter-spring transition, Skeletonema costatum (0.540) was clearly the dominant species at the oyster farm, followed by Rhizosolenia delicatula (0.128). The kelp farm was dominated by $S$. costatum (0.165) followed by Thalassiosira sp. 1 (0.146). Prorocentrum minimum (0.340) was clearly the dominant species at the fish farm, followed by $R$. delicatula (0.158) and Thalassiosira sp. 1 (0.135).

Fig. 5 shows little difference among the dominant phytoplankton at the stations and in water layers. The dominance of Skeletonema costatum ( 45.6 to $60.1 \%$ ) inside the culture area was a little lower than outside. The opposite was true for Prorocentrum minimum and Thalassiosira sp. 1. In winter, the dominance of $P$. minimum was higher outside than inside the oyster farm; the opposite was true for Navicula corymbosa. In spring, the dominance of Melosira sp. outside the farm was higher than inside; the opposite was true for Thalassiosira sp. 1. There were significant dominant gradation differences among the different stations and water layers at the kelp 
farm (Fig. 6). For example, during the winter-spring transition, the dominances of $S$. costatum in surface water at Stns LC0 $(35.9 \pm 5.4 \%$, mean $\pm \mathrm{SD})$ and LC1 $(28.9 \pm 4.4 \%)$ were significantly $(p<0.001)$ higher than at Stns LC2 $(11.1 \pm 5.0 \%)$ and LC3 $(10.3 \pm$ $4.0 \%$ ). In contrast, the dominances of Thalassiosira sp. 1 shown in Fig. 7 revealed no conspicuous variance among the different stations and water layers.

\section{Cluster analysis}

Both NMDS and cluster analysis showed that the phytoplankton community in culture areas could be generally classified into 3 groups according to culture systems (Figs. $8 \& 9$ ). The 3 culture systems were relatively different from each other (see the results of ANOSIM in Table 5).

\section{Canonical correspondence analysis}

The CCA showed higher p-values for axis 1 and all canonical axes in all

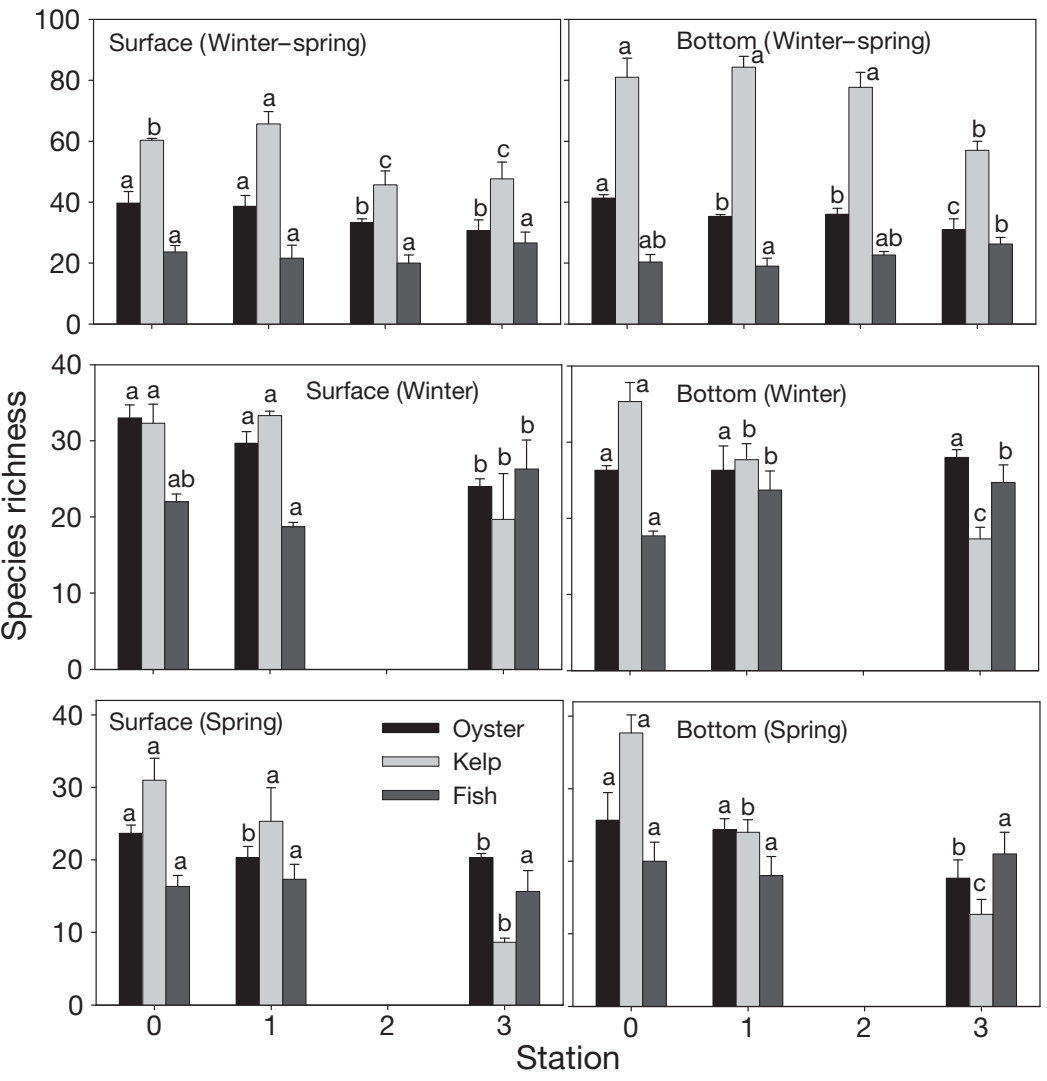

Fig. 4. Species richness $(S)$ of phytoplankton at different sampling stations in 3 culture systems during the winter-spring transition, winter, and spring. See Figs. 2 \& 3 for details

Table 4. Dominant $(\geq 0.02)$ phytoplankton species at the oyster, kelp, and fish farms of Xiangshan Bay in different seasons

\begin{tabular}{|c|c|c|c|c|c|c|c|c|c|}
\hline \multirow[t]{2}{*}{ Species } & \multicolumn{3}{|c|}{ Winter-spring } & \multicolumn{3}{|c|}{ - Winter } & \multicolumn{3}{|c|}{ - Spring } \\
\hline & Oyster & Kelp & Fish & Oyster & Kelp & Fish & Oyster & Kelp & Fish \\
\hline Chaetoceros abnormis & 0.043 & 0.045 & - & - & - & - & - & - & 0.044 \\
\hline Coscinodiscus curvatulus & - & - & 0.033 & - & - & 0.058 & - & - & - \\
\hline Coscinodiscus jonesianus & - & - & - & 0.043 & 0.085 & 0.185 & 0.037 & 0.278 & 0.083 \\
\hline Cyclotella sp. & 0.069 & 0.094 & - & - & - & - & - & - & - \\
\hline Ditylum brightwelli & 0.025 & 0.072 & - & 0.092 & 0.063 & 0.060 & - & - & - \\
\hline Melosira sp. & - & - & - & - & - & - & 0.214 & - & 0.168 \\
\hline Navicula corymbosa & - & 0.034 & 0.026 & 0.037 & 0.021 & 0.026 & - & 0.024 & - \\
\hline Nitzschia hungarica & - & - & 0.024 & - & 0.026 & - & - & - & - \\
\hline Nitzschia subtilis & - & - & - & - & - & 0.027 & - & - & - \\
\hline Paralia sulcata & - & 0.025 & 0.027 & - & 0.045 & - & - & - & - \\
\hline Pleurosigma aestuarii & - & - & - & - & 0.023 & 0.056 & - & - & - \\
\hline Rhizosolenia delicatula & 0.128 & 0.075 & 0.158 & - & - & - & - & - & - \\
\hline Skeletonema costatum & 0.540 & 0.165 & - & 0.070 & 0.082 & - & 0.057 & - & 0.048 \\
\hline Thalassiosira sp. 1 & 0.049 & 0.146 & 0.135 & 0.302 & 0.322 & 0.133 & 0.432 & 0.191 & 0.373 \\
\hline Thalassiosira pacifica & - & - & 0.035 & 0.024 & - & - & 0.042 & 0.078 & 0.047 \\
\hline Prorocentrum minimum & 0.037 & 0.090 & 0.340 & 0.208 & 0.182 & 0.111 & - & 0.031 & 0.022 \\
\hline Prorocentrum sigmoides & - & - & - & - & - & - & 0.029 & 0.106 & 0.054 \\
\hline Protoperidinium spp. & - & - & - & - & - & 0.031 & - & - & - \\
\hline
\end{tabular}




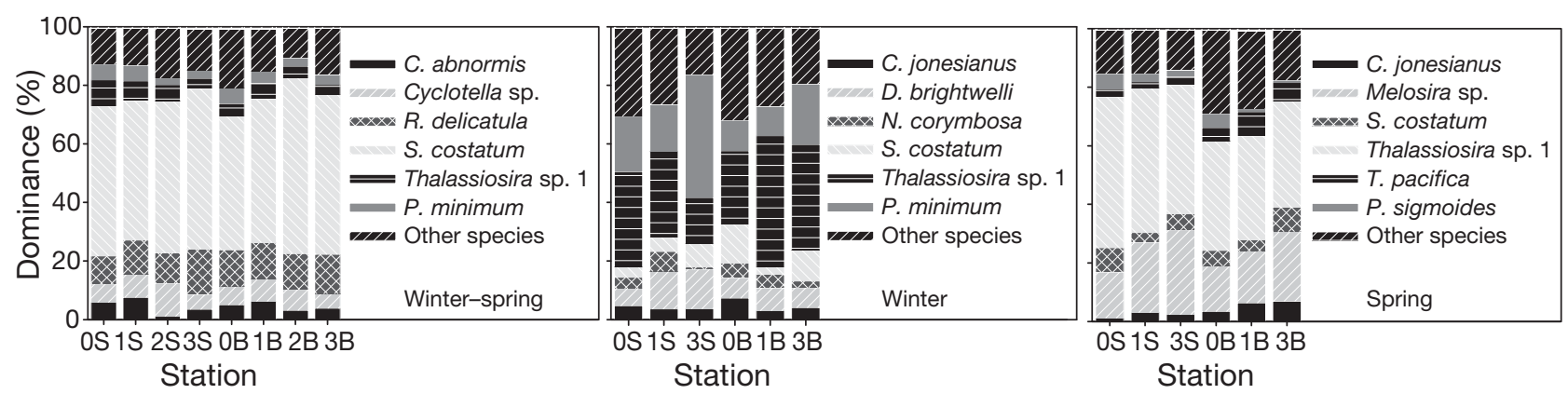

Fig. 5. Main dominant phytoplankton species at different sampling stations at the oyster farm during the winter-spring transition, winter, and spring. See Figs. $2 \& 3$ for details. Full species names in Table 4

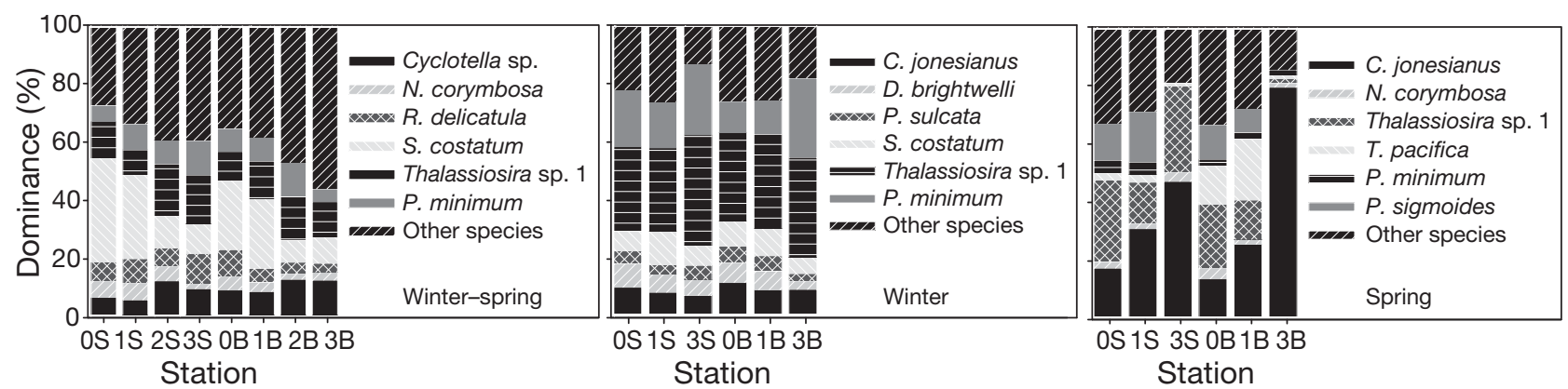

Fig. 6. Main dominant phytoplankton species at different sampling stations at the kelp farm during the winter-spring transition, winter, and spring. See Figs. 2 \& 3 for details. Full species names in Table 4
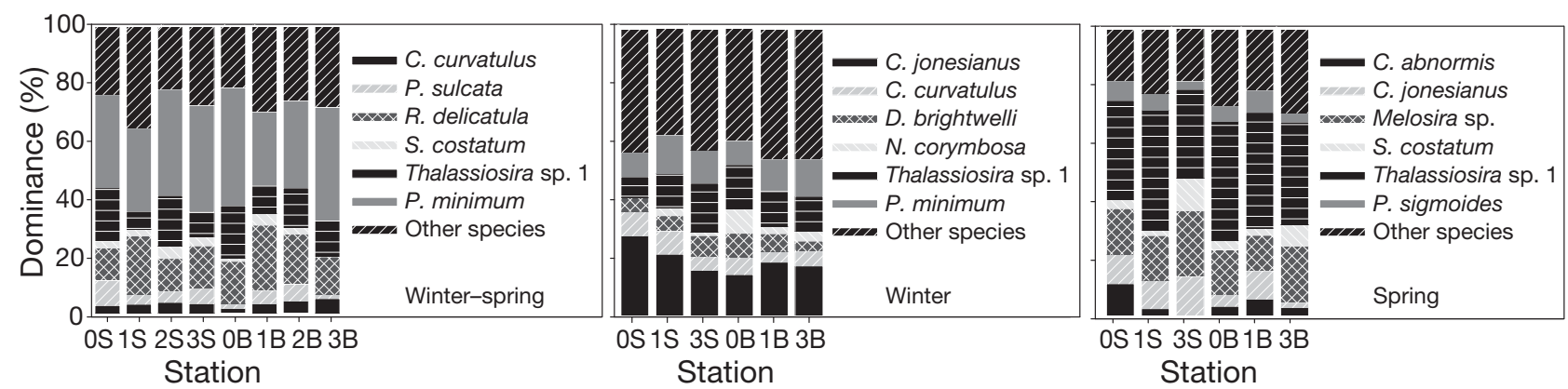

Fig. 7. Main dominant phytoplankton species at different sampling stations at the fish farm during the winter-spring transition, winter, and spring. See Figs. 2 \& 3 for details. Full species names in Table 4

the seasons, based on the Monte Carlo test (Table 6). Hence, the ordination results were credible. The 9 environmental variables in the CCA explained 62.5, 64.1 and $64.9 \%$ of total variation in the phytoplankton community during the winter-spring transition, winter and spring, respectively. All species-environment correlations were $>0.83$ for Axes 1 and 2, indicating a significant $(p<0.05)$ relationship between each of the environmental variable and the dominant phytoplankton. Temperature, nutrients (DIN, $\mathrm{SiO}_{3}-$ $\mathrm{Si}, \mathrm{PO}_{4}-\mathrm{P}$, and N/P), salinity, and $\mathrm{SS}$ were the main variables that affected phytoplankton community distribution as a whole (Fig. 9), although small differences existed in different sampling periods.
Five main groups of species were distinguished according to the ordination result (Fig. 10). Group I: benthic or epiphytic species (e.g. Actinocyclus ehrenbergii, Actinoptychus undulates, Diploneis smithii, Melosira moniliformis, Pleurosigma aestuarii, and the genera Navicula and Nitzschia) with high SS. Group II: estuarine or brackish planktonic species (e.g. Caloneis silicula, C. abnormis, Synedra gailloni, and the genus Cyclotella) with low salinity, such as Caloneis silicula, C. abnormis, Cyclotella spp. and Synedra gaillonii. Group III: planktonic species (e.g. Leptocylindrus minimus and Asteroplanus karianus) sensitive to the temperature. Group IV: coastal innerbay diatoms (e.g. Thalassionema nitzschioides and 


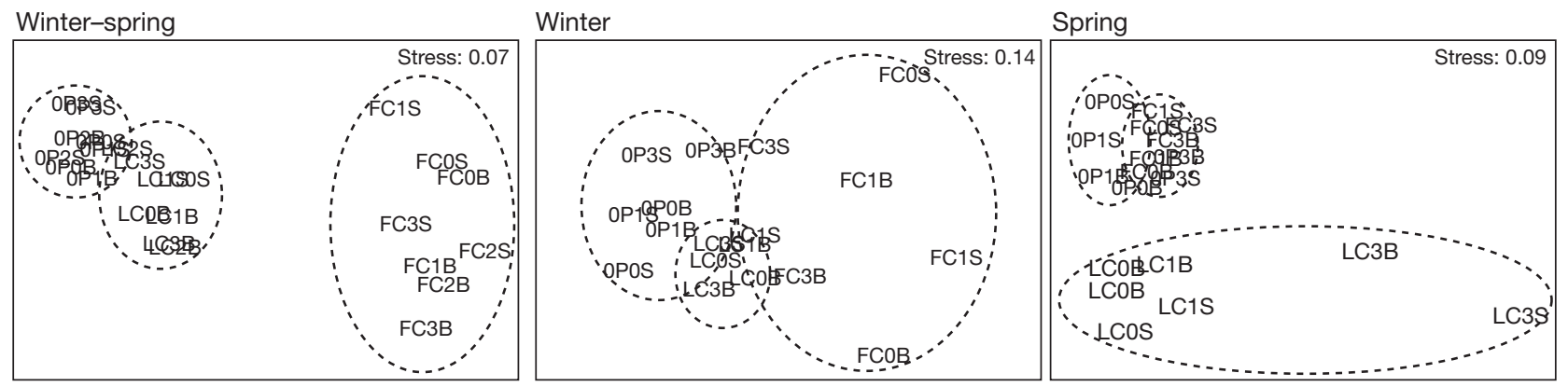

Fig. 8. Non-metric multidimensional scaling (NMDS) of species abundance data collected from surface (S) and bottom (B) waters at the oyster (OP), kelp (LC), and fish (FC) farm stations during the winter-spring transition, winter, and spring. See Fig. 2 for further details of seasons and stations
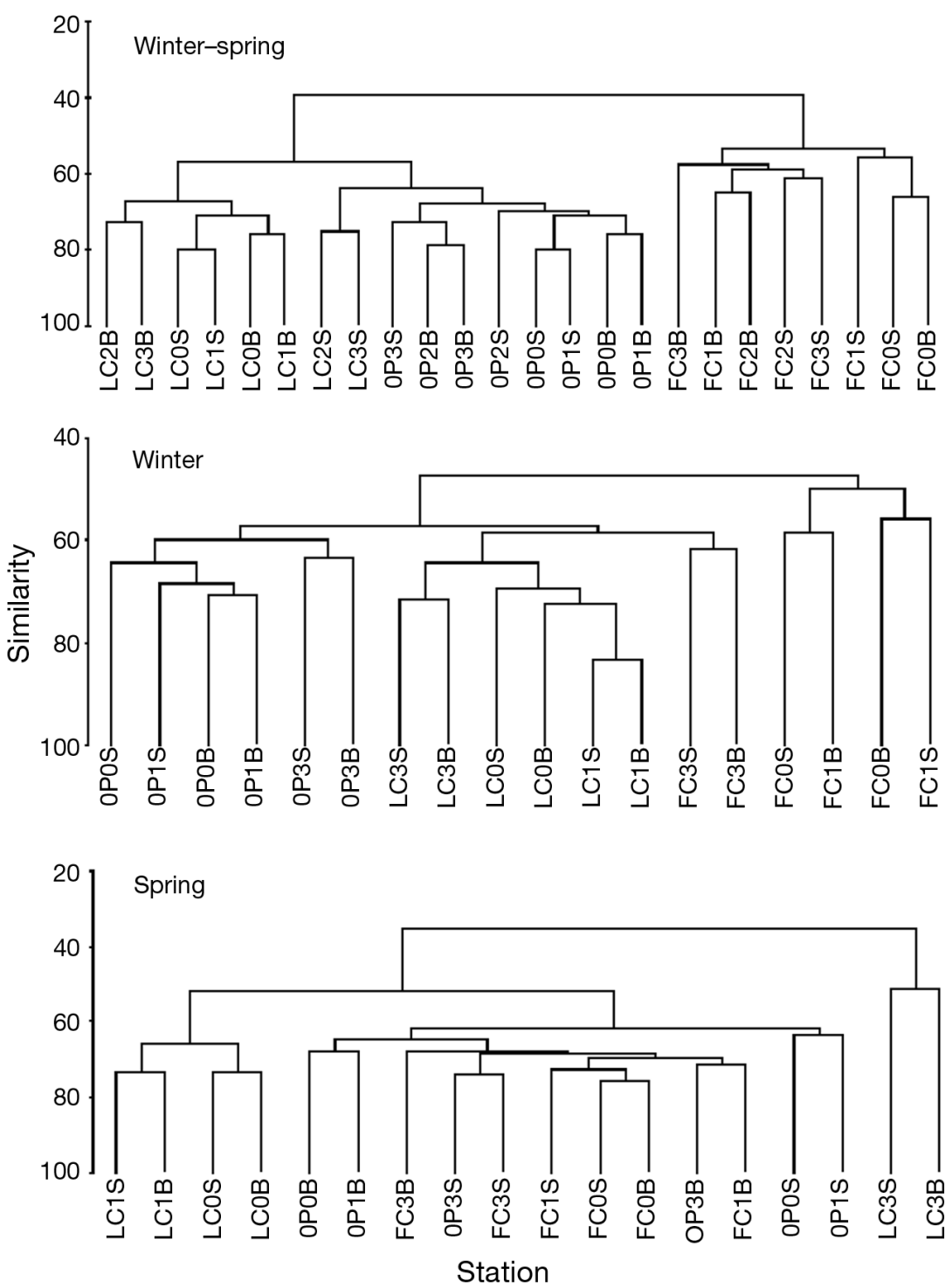

Fig. 9. Clusters analysis based on Bray-Curtis similarity matrix of oyster (OP), kelp (LC), and fish (FC) farm stations sampled during the winter-spring transition, winter, and spring. See Fig. 2 for further details of seasons and stations the genus Coscinodiscus), dinoflagellates (e.g. Scrippsiella trochoidea and the genus Prorocentrum), and Chlorophyceae (Pyramidomonas sp.) which prefer high $\mathrm{DIN}, \mathrm{SiO}_{3}-\mathrm{Si}$, and N/P; Group V: relative eurythermal and euryhaline planktonic species (near the centre of the ordination) that were more tolerant to environmental stress, such as Ditylum brightwellii, Nitzschia longissima, and the genus Thalassiosira.

\section{DISCUSSION}

\section{Phytoplankton and environmental parameters at the oyster farm}

The oyster farm was located near the outfall of the Ninghai Power Plant (operating since December 2005, Fig. 1). This farm was surrounded by water with $1^{\circ} \mathrm{C}$ temperature elevation caused by the large thermal discharges $\left(82.5 \mathrm{~m}^{3} \mathrm{~s}^{-1}\right)$. Given the long residence time $(80 \mathrm{~d})$ in the inner bay for $90 \%$ water exchange, thermal effluents remained in the oyster farm for a relatively long time. The field temperature in winter $\left(9.9^{\circ} \mathrm{C}\right)$ and winter-spring transition $\left(11.5^{\circ} \mathrm{C}\right)$ were close to the optimal growth temperature of dominant species Skeletonema costatum $\left(17\right.$ to $25^{\circ} \mathrm{C}$; Yan et al. 2002) and Prorocentrum minimum (18 to $26.5^{\circ} \mathrm{C}$; Grzebyk \& Berland 1996). Hence, there were relatively high cell

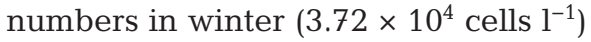


and spring $\left(2.31 \times 10^{4}\right.$ cells l$\left.^{-1}\right)$ of 2010 at this farm (Table 2). These values were much higher than those of the same seasons in $2000\left(0.22\right.$ and $0.77 \times 10^{4}$ cells $\mathrm{l}^{-1}$, respectively; Ning \& Hu 2002). Overall, P was limiting in the inner Xiangshan Bay, but the $\mathrm{PO}_{4}-\mathrm{P}$ concentration at the oyster farm was relatively higher than in the other culture areas. This area had favorable conditions of temperature elevation, good light permeation, and flow velocity reduction (due to oysters attaching to racks and ropes). Hence, phytoplankton species (e.g. S. costatum, Thalassiosira spp., Rhizosolenia delicatula, and P. minimum) consumed mass nutrients to promptly reproduce and formed blooms in winter and the winter-spring transition $\left(81.60 \times 10^{4}\right.$ cells $\left.^{-1}\right)$. Consequently, DIN and $\mathrm{SiO}_{3}-\mathrm{Si}$ decreased and DO increased (Table 2).

Phytoplankton $S$ was remarkably higher inside the farm than outside (Fig. 4), whereas the cell number and chl $a$ inside were lower than outside (Figs. $2 \& 3$ ).

Table 5. One-way ANOSIM results of phytoplankton community among oyster, kelp, and fish farms of Xiangshan Bay in different seasons. $R$ is the statistic coefficient which indicates the magnitude of difference among groups of samples

\begin{tabular}{|lcccccc|}
\hline & \multicolumn{3}{c}{ Winter-spring } & \multicolumn{2}{c|}{ Winter } & \multicolumn{2}{c|}{ Spring } \\
& $R$ & $\mathrm{p}$ & $R$ & $\mathrm{p}$ & $R$ & $\mathrm{p}$ \\
\hline Oyster vs. Kelp & 0.87 & 0.001 & 0.70 & 0.002 & 0.55 & 0.002 \\
Oyster vs. Fish & 1.00 & 0.001 & 0.64 & 0.002 & 0.20 & 0.41 \\
Kelp vs. Fish & 0.99 & 0.001 & 0.42 & 0.002 & 0.55 & 0.002 \\
Global test & 0.84 & 0.001 & 0.51 & 0.001 & 0.45 & 0.001 \\
& & & & & & \\
\hline
\end{tabular}

Table 6. Summary of the canonical correspondence analysis on phytoplankton communities and environmental variables in culture areas of Xiangshan Bay in different seasons

\begin{tabular}{|c|c|c|c|c|c|c|}
\hline & \multicolumn{2}{|c|}{ Winter-spring } & \multicolumn{2}{|c|}{ Winter } & \multicolumn{2}{|c|}{ Spring } \\
\hline Eigenvalues & 0.153 & 0.031 & 0.087 & 0.056 & 0.199 & 0.043 \\
\hline $\begin{array}{l}\text { Species-environment } \\
\text { correlations }\end{array}$ & 0.855 & 0.831 & 0.966 & 0.945 & 0.978 & 0.901 \\
\hline $\begin{array}{l}\text { Cumulative } \\
\text { percentage variance } \\
\text { of species data }\end{array}$ & 38.3 & 46.0 & 24.1 & 39.5 & 39.2 & 47.7 \\
\hline $\begin{array}{l}\text { Species-environment } \\
\text { relation }\end{array}$ & 61.2 & 73.6 & 37.6 & 61.7 & 60.4 & 73.5 \\
\hline Sum of all eigenvalues & 0.400 & & 0.362 & & 0.507 & \\
\hline $\begin{array}{l}\text { Sum of all canonical } \\
\text { eigenvalues }\end{array}$ & 0.250 & & 0.232 & & 0.329 & \\
\hline Variance explained & $62.5 \%$ & & $64.1 \%$ & & $64.9 \%$ & \\
\hline $\begin{array}{l}\text { Significance of first } \\
\text { canonical axis }\end{array}$ & 0.016 & & 0.006 & & 0.002 & \\
\hline $\begin{array}{l}\text { Significance of all } \\
\text { canonical axes }\end{array}$ & 0.006 & & 0.016 & & 0.022 & \\
\hline
\end{tabular}

These results revealed that oyster farming reduced cell numbers by filtering microalgae (top-down control), which is supported by many previous reports (Dupuy et al. 2000, Souchu et al. 2001, Huang et al. 2008, Grangeré et al. 2010). Large numbers of epibiotic microalgal taxa were found. These taxa elevated the species richness and diversity, although their abundances were very low. The water temperature ( 9.9 to $15.2^{\circ} \mathrm{C}$ ) from winter to spring was also too low for oyster growth, resulting in a lower energy budget for oysters (Mao et al. 2006) and decreased phytoplankton consumption. In the summer, the cultured oysters and biofouling assemblages that attach to the rafts and longlines filter large volumes of microalgae from the water column, due to their highest levels of metabolism and growth rates (Mazouni et al. 2001, Mao et al. 2006).

\section{Phytoplankton and environmental parameters at the kelp farm}

The levels of DIN and $\mathrm{PO}_{4}-\mathrm{P}$ inside the kelp area were slightly lower than those outside. This finding may be related to the small size of the farm and the high level of nutrients in background waters. Except for surface abundance in the winter-spring transition, the cell number inside the kelp farm was significantly higher than outside (Fig. 3). The nitrogen storage and nitrogen-dependent growth rates of micro- and macroalgae indicate that microalgae would be superior under high nutrient availability, whereas the slowgrowing macroalgae would be superior under low nutrient availability (Pedersen \& Borum 1996). In the present study, under high nutrient availability (Table 2), phytoplankton growth was not suppressed by macroalgae in winter and spring, in accordance with the above-mentioned deduction. Trophic competition and allelopathic effects between microalgae and kelp were also not severe. An et al. (2008) have reported the possible existence of allelopathic effects between kelp and microalgae, given that phytoplankton growth is inhibited during the winter-spring transition. Kelp and other macroalgae can release allelopathic substances to inhibit microalgal growth and even cause mortal- 
ity, although macroalgae have different inhibiting effects on different microalgae (Wang et al. 2007). Therefore, the allelopathic effects between microand macro-algae require further scrutiny.

There were many epiphytic microalgal taxa (e.g. the genera Diploners, Gyrosigma, Licmophora, Navicula, Nitzschia, Pleurosigma, and Synedra) attached to kelp thalli, which accounted for increased $S$ inside
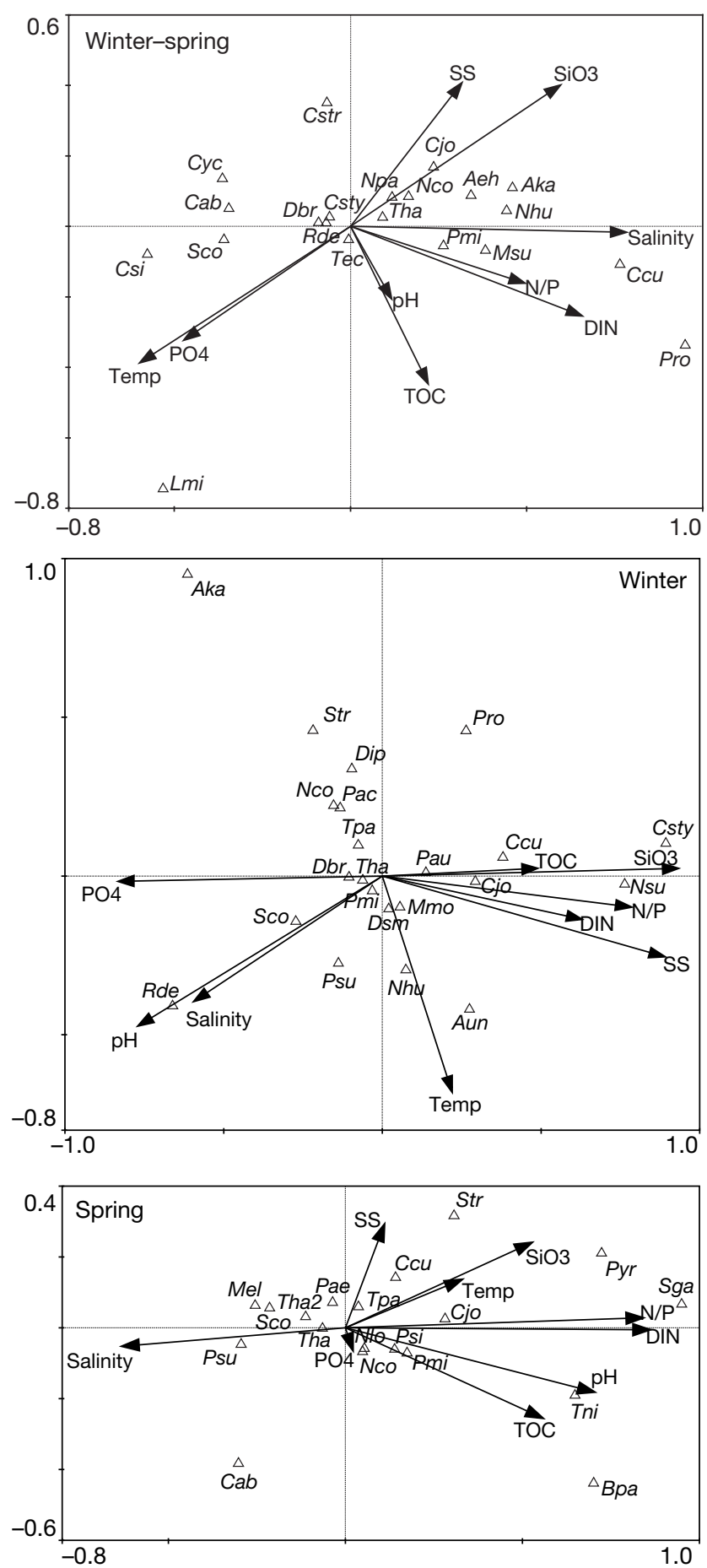

the kelpfarm (Fig. 4). There were significant differences among dominances at different stations. For example, the dominance of Skeletonema costatum inside the kelp farm was significantly higher than that outside during the winter-spring transition. There are 2 possible reasons for this. First, there were microalgal species differences in the allelopathic effects of kelp, and $S$. costatum may be more tolerant to this stress than other species. Second, under flow velocity reduction caused by cultured kelp, the chain length of $S$. costatum inside the farm becomes longer than that outside. Therefore, decreased sinking rates likely help the diatom to remain suspended in the upper part of the water column (Takabayashi et al. 2006), although this requires further confirmation.

\section{Phytoplankton and environmental parameters at the fish farm}

Little feeding and low excretion rates have been observed in a Japanese seaperch farm during winter and the winter-spring transition (Ning \& Hu 2002), because the low temperature negatively affects fish growth. In the present study, with the relatively quick dilution and extremely high concentration of nutrients in background waters, the nutrient concentrations (DIN, $\mathrm{NH}_{3}-\mathrm{N}, \mathrm{PO}_{4}-\mathrm{P}$ and TOC) inside the farm were a little higher than outside at these times (Fig. 2). However, with increased temperature in spring, feeding and excretion increased. Consequently, the levels of nutrients and organic matter

Fig. 10. Canonical correspondence analysis ordination of phytoplankton communities with environmental variables, based on data collected from the 3 culture areas of Xiangshan Bay during the winter-spring transition (02/2009), winter (01/2010), and spring (04/2010). Aeh: Actinocyclus ehrenbergii; Aka: Asteroplanus karianus; Aun: Actinoptychus undulates; Bpa: Bacillaria paxillifera; Csi: Caloneis silicula; Cab: Chaetoceros abnormis; Ccu: Coscinodiscus curvatulus; Cjo: Coscinodiscus jonesianus; Cstr: Cyclotella striata; Csty: Cyclotella stylorum; Cyc: Cyclotella sp.; Dbr: Ditylum brightwellii; Dsm: Diploneis smithii; Lmi: Leptocylindrus minimus; Mmo: Melosira moniliformis; Mel: Melosira sp.; Nco: Navicula corymbosa; Npa: Navicula parva; Nhu: Nitzschia hungarica; Nlo: Nitzschia longissima; Nsu: Nitzschia subtilis; Pac: Pleurosigma acutum; Pae: Pleurosigma aestuarii; Psu: Paralia sulcata; Rde: Rhizosolenia deliCatula; Sco: Skeletonema costatum; Sga: Synedra gaillonii; Tin: Thalassionema nitzschioides; Tha: Thalassiosira sp. 1; Tpa: T. pacifica; Tha2: Thalassiosira sp. 2; Dip: Diplopsalis sp.; Pmi: Prorocentrum minimum; Psi: P. sigmoides; Pro: Protoperidinium spp.; Str: Scrippsiella trochoided; Pyr: Pyramidomonas sp. SS: suspended solids; DIN: dissolved inorganic nitrogen; TOC: total organic carbon 
inside the farm became much higher than outside. In the central cultivating area, $\mathrm{NH}_{3}-\mathrm{N}$ was twice as high as at the station $1000 \mathrm{~m}$ away from the edge. The nutrients that were discharged from feeding and remained as organic particles (mostly from unconsumed feed and fecal material) accumulated in the sediments (Dong et al. 2008, Lauer et al. 2009), as evidenced by the high concentrations of sediment TN, TP and TOC at sampling stations (authors unpubl. data). With the increased temperature in spring, more nitrogen was discharged from sediments, causing the levels of $\mathrm{NH}_{3}-\mathrm{N}$ and DIN in bottom water inside the farm to become significantly higher than outside. These data indicate that (as well as terrestrial load) the fish farm was a source of $N, P$, and organic carbon. Nobre et al. (2010) estimated nutrient loads from catchments to be about $4015 \mathrm{t}$ $\mathrm{yr}^{-1}$ of DIN and $730 \mathrm{t} \mathrm{yr}^{-1}$ of P. About $2534 \mathrm{t} \mathrm{yr}^{-1}$ of DIN and $1039 \mathrm{t} \mathrm{yr}^{-1}$ of $\mathrm{P}$ came from fish cages. Therefore, the high level of eutrophication mainly resulted from catchment input and excessive aquaculture activities. However, the levels of DIN $\left(0.596 \mathrm{mg} \mathrm{l}^{-1}\right)$ and $\mathrm{NH}_{3}-\mathrm{N}\left(0.030 \mathrm{mg} \mathrm{l}^{-1}\right)$, and the ratio N/P (24.8) in the fish farm in 2010 were lower than in 2000 (Ye et al. 2002). The annual averages were $0.766 \mathrm{mg} \mathrm{l}^{-1}$ for DIN, $0.081 \mathrm{mg} \mathrm{l}^{-1}$ for $\mathrm{NH}_{3}-\mathrm{N}$, and 45.2 for the N/P ratio. The $\mathrm{PO}_{4}-\mathrm{P}$ concentration in 2000 (0.057 $\mathrm{mg} \mathrm{l}^{-1}$ ) was higher than in $2010\left(0.031 \mathrm{mg} \mathrm{l}^{-1}\right)$. The decrease in the farm scale may be the reason for these differences between 2000 and 2010 .

The phytoplankton cell number inside the fish farm was significantly lower than outside in winter, but samples from other seasons showed no remarkable differences. This result supports those of previous studies that have failed to establish a clear relationship between fish farm inputs and phytoplankton biomass (Alongi et al. 2003, Navarro et al. 2008, Sidik et al. 2008). Microalgal (especially diatoms) growth in the fish farm was inhibited by the extreme P limitation in winter $(\mathrm{N} / \mathrm{P}=30.9)$ and in the winter-spring transition $(\mathrm{N} / \mathrm{P}=30.4)$, resulting in the low phytoplankton abundance and high dominances $(0.111$ and 0.340 , respectively) of Prorocentrum minimum. Dinoflagellate species have been reported to cause a harmful bloom and low diatom/dinoflagellate ratio in a fish farm in Cape Bolinao, Philippines (San DiegoMcGlone et al. 2008). There were negligible differences in abundances, dominant species and $S$ at different stations in the fish farm in the present study, possibly due to the negligible spatial heterogeneity of environmental parameters (Fig. 2). Red tide outbreaks of several species (mostly diatoms), such as Skeletonema costatum, Chaetoceros socialis, Paralia sulcata and Prorocentrum donghaiense, have previously occurred in the study area (You \& Jiao 2011). No report of a $P$. minimum red tide has been recorded so far, but its possibility should not be ignored because it is toxic to fish and other animals.

\section{Relationship between phytoplankton communities and environmental factors}

Samples were collected from 3 culture systems on different days during the cruise. Nevertheless, the results of our investigation of culture types are credible and comparable because the influence of sampling time differences can be ignored. The water exchange rate is low in the bay, with a long residence time in the inner and middle sections of about 80 and $60 \mathrm{~d}$, respectively, for $90 \%$ water exchanges. The hydrologic regime is dominated by reciprocating fluid. Hence, water mixing is not apparent (Dong \& $\mathrm{Su} 2000$ b) and the water body is stable within a relatively short sampling period.

In the present study, different culture types formed different small-scale habitats, exhibiting various environmental gradients and forms of phytoplankton community patchiness. Despite the ANOSIM showing significant differences among the culture systems (Table 5), the phytoplankton communities at the oyster and kelp farms were relatively similar during winter and the winter-spring transition (Figs. 8 \& 9). The similarity can be attributed to the co-dominant species and homologous epibiotic microalgal species at both farms. The dominant phytoplankton species were divided into 5 main groups along with environmental gradations by CCA ordination (Fig. 10). The CCA perfectly exhibited the spatial distribution of dominant phytoplankton taxa and the environmental variables.

Temperature and nutrition were the most important variables that affected the phytoplankton communities, according to the CCA results (Fig. 9). The temperature elevation caused by thermal discharges from the power plant apparently triggered the blooms of Thalassiosira sp. 1 and Prorocentrum minimum in winter and Skeletonema costatum in the winter-spring transition. In fact, before the power plant was constructed, microalgal blooms usually occurred during late spring (May) or early summer (June) in the Xiangshan Bay. However, since the power plant became operational in December 2005, red tide outbreaks have occurred in January 2006 and 2009. This change indicates that a moderate temperature increase distinctly promotes phyto- 
plankton growth, based on the results of laboratory experiments (Liao et al. 2008) and field surveys in the present study. Compared with historical data, nutrient levels and proportions in (or near) the culture area of Xiangshan Bay have changed remarkably (Table 7). This change has also led to a variation in microalgal community composition under the abovementioned thermal stress, as evidenced by phytoplankton taxa being co-dominated by diatoms and dinoflagellates from winter to spring. These results are not consistent with earlier ones (prior to operation of the power plant), wherein only diatoms dominated (Table 8).

\section{Evaluation and suggestions for the 3 cultivation types}

Oyster cultures have been proposed as ecological restoration tools for the top-down control of phytoplankton blooms and for reversing eutrophication in coastal waters (Newell 2004, Coen et al. 2007, Huang

Table 7. Comparison of nutrient concentration $\left(\mathrm{mg} \mathrm{l}^{-1}\right)$ and structure in (or near) the present study survey areas in winter and spring during different years. DIN: dissolved inorganic nitrogen

\begin{tabular}{|c|c|c|c|c|c|}
\hline Year & Season & DIN & $\mathrm{PO}_{4}-\mathrm{P}$ & N/P & Source \\
\hline 1981 & Winter & 0.252 & 0.020 & 27.9 & ЕСВCC (1992) \\
\hline 2010 & Winter & 0.679 & 0.055 & 27.3 & This study \\
\hline 1982 & Spring & 0.299 & 0.0222 & 29.8 & ECBCC (1992) \\
\hline 1992 & Spring & 0.291 & 0.0055 & 88.27 & \\
\hline 2006 & Spring & 0.644 & 0.0512 & 27.9 & Lü et al. (2009) \\
\hline 2007 & Spring & 0.730 & 0.0488 & 33.1 & \\
\hline 2010 & Spring & 0.535 & 0.079 & 15.2 & This study \\
\hline
\end{tabular}

et al. 2008), although their ecosystem service functions are currently controversial (Pomeroy et al. 2006, Fulford et al. 2007, Newell et al. 2007, Brigolin et al. 2009). Oysters and their biofouling assemblages (e.g. ascidians, bryozoans, sponges, polychaetes and macroalgae; Mazouni et al. 2001) indirectly or directly remove nutrients by filtering phytoplankton and other microbial particles. Cumulated faeces and pseudo-faeces on the sea-bed are released into the water column under suitable conditions, even though the harvest represents a net removal of $\mathrm{N}$ and $\mathrm{P}$ from the ecosystem (Brigolin et al. 2009). Nevertheless, as an important habitat restoration technique, oyster farms and created oyster reefs have been widely adopted (Rodney \& Paynter 2006, Taylor \& Bushek 2008, Quan et al. 2009). These structures are recognized as key marine habitats that have numerous economic and ecological benefits. Such benefits include commercial fisheries (Peterson et al. 2003), water quality purification (Newell 2004), biodiversity conservation (Thomsen et al. 2007), benthic fauna and reef fish habitat provision (Rodney \& Paynter 2006, Tallman \& Forrester 2007, Quan et al. 2009), as well as the functions of benthic-pelagic coupling and biogeochemistry circulation (Dupuy et al. 2000, Newell 2004, Zhou et al. 2006). Oyster carapace growth by mass organic carbon consumption from the seawater via calcification is also considered as one method of carbon sink formation (Hung \& Kuo 2002, Tang et al. 2011). Therefore, we support oyster culture in coastal waters. However, the culture location must be adjusted temporally according to the biota and deposited organic matter to maximise the ecological and economic benefits. Nobre et al. (2010) have predicted that shellfish (93\% oyster) production in the inner section of the Xiangshan Bay will gener-

Table 8. Comparison of phytoplankton dominant species at (or near) the present study survey areas in winter and spring during different years

\begin{tabular}{|lllc|}
\hline Year & Season & Dominant species & Source \\
\hline 1981 & Winter & Nitzschia, Skeletonema, Leptocylindrus, Coscinodiscus and Chaetoceros & ECBCC (1992) \\
2000 & Winter & Chaetoceros, Cyclotella, Leptocylindrus and Melosira & Ning \& Hu (2002) \\
2007 & Winter & Cerataulina, Chroococlus and Skeletonema & You \& Jiao (2011) \\
2008 & Winter & Skeletonema, Melosira, Pleurosigma, Biddulphia and Bacillaria & You \& Jiao (2011) \\
2009 & Winter & Skeletonema & You \& Jiao (2011) \\
2010 & Winter & Skeletonema, Coscinodiscus, Ditylum, Thalassiosira and Prorocentrum & This study \\
1982 & Spring & Coscinodiscus, Nitzschia, Rhizosolenia and Melosira & ECBCC (1992) \\
2000 & Spring & Skeletonema, Navicula and Paralia & Ning \& Hu (2002) \\
2007 & Spring & Skeletonema, Licmophora and Coscinodiscus & You \& Jiao (2011) \\
2008 & Spring & Skeletonema and Coscinodiscus & You \& Jiao (2011) \\
2009 & Spring & Coscinodiscus and Skeletonema & You \& Jiao (2011) \\
2010 & Spring & Coscinodiscus, Thalassiosira, Melosira, Skeletonema and Prorocentrum & This study \\
\hline
\end{tabular}


ally decrease by 10 to $28 \%$. This prediction is based on the fact that shellfish growth is sustained by the substances to be reduced for the improvement of water quality. Therefore, it is advisable to reallocate part of the oyster culture towards the mouth of the embayment.

Many researchers believe that large-scale seaweed cultivation, which is economically and ecologically sustainability, is a good solution to the eutrophication problem in coastal waters (Fei 2004, Neori et al. 2004, Yang et al. 2004, He et al. 2008). Macroalgal remediation not only plays a key role in the sustainable expansion of aquacluture, but also alleviates pollution and takes up a significant volume of coastal carbon. These processes effectively eliminate the nutrient load and perennially control coastal eutrophication. As sources of human food, medicaments, light industrial products and marine faunal feed, seaweeds usually have high economic value. Seaweeds also fully consume dissolved nutrients in culture wastewater and yield a high value product. The unit culture system output, culture animal quality and production, as well as cost reduction improved (Neori et al. 2004). In addition, seaweeds are important components of habitats of marine biota because they increase the spatial heterogeneity and biodiversity by altering local hydrodynamic regimes (e.g. turbidity, flow velocity, sediment transmission, and resuspension reduction). Therefore, the cultivation of seaweeds (such as Gracilaria lemaneiformis, which is more tolerant to high temperature) in warm seasons, and kelp (or Porphyra haitanensis) in cold seasons should be strongly recommended in eutrophic areas.

The negative effects of the fish farm on the environment are the highest among the culture systems, but its economic benefit may also be the highest. Low feeding efficiency caused by high culture density and feeding quantity (intensive cage farming) usually leads to the mass loss of nutrients (Islam 2005). The level of nutrient loadings would be several orders of magnitude higher in the areas where live feed (e.g. trash fish) is used. $\mathrm{N}$ and $\mathrm{P}$ from fish cages ( $61 \%$ of food waste) are the major contributors of eutrophication (nutrients) in Xiangshan Bay, based on multilayered ecosystem models (Nobre et al. 2010). These discharged nutrients lead to oxygen depletion, water deterioration, and eutrophication aggravation of aquacultural regions as well as their adjacent waters (Alongi et al. 2003). This fact is especially true in weak water-exchange semi-closed fiords with high culture density, wherein net culture is prone to inducing red tides (David et al. 2009). Unfortunately, fish cages in China are mostly located in semi-closed bays, and the fish are usually fed with excessive amounts of fresh trash fish and formulated diets for high yield. Such a practice results in high accumulation of organic matter in the sediment, including unconsumed feedstuff, dejecta and faeces. The deposited $\mathrm{N}, \mathrm{P}$, and organic matter are also released into the bottom and surface water under certain conditions (Dong et al. 2008, Lauer et al. 2009), thereby causing re-pollution and eutrophic process aggravation. In the present study, the enrichment of organic matter in the sediment was found to be accompanied by a strong feculent odour and deep anoxic layer at the fish cage, as has also been previously reported (Hu et al. 2001, Ning \& Hu 2002, Holmer \& Heilskov 2008). From the perspective of eutrophication control, nutrient loads from cages, which remain in high proportion and long-term lag phase in the Xiangshan Bay, need to be managed and reduced. However, if the fish farm is settled on the open, deep sea area with a strong hydrodynamic regime, the negative effects on the environment are negligible (Vezzulli et al. 2008). Therefore, we suggest that an offshore site is a better location for cages. Alternatively, a macroalgal polyculture can be adopted at the fish farm to assimilate excessive $\mathrm{N}$ and $\mathrm{P}$.

\section{CONCLUSIONS}

Different culture types formed different small-scale habitats, exhibiting various environmental gradients and forms of phytoplankton community patchiness. The environmental and phytoplankton variables were found to be significantly different among 3 culture habitats. The distribution of the phytoplankton community was mainly influenced by temperature, nutrients (DIN, $\mathrm{SiO}_{3}-\mathrm{Si}_{1} \mathrm{PO}_{4}-\mathrm{P}$, and N/P), salinity, and SS. The oyster and kelp farms effectively alleviated coastal eutrophication and increased phytoplankton species richness and diversity. The fish farm did not. Microalgal abundance drastically decreased in all survey seasons at the oyster farm, but not at the kelp and fish farms. Although the temperature elevation caused by thermal discharge from a power plant induced blooms in winter and the winter-spring transition, suspended oysters effectively filtered and reduced phytoplankton biomass under the disadvantageous conditions of low-level metabolism and growth rate. Thermal effects should not be ignored or underestimated. Considering the recent construction of more power plants in Chinese bays where mariculture is established, great efforts should be invested into the study of the phytoplankton responses to cul- 
ture eutrophication under thermal stress. In terms of water quality, phytoplankton variables and habitat restoration functions, the kelp and oyster farms were much better than the fish farm. The kelp and oyster farms also had no extrinsic energy input or infliction, but exhibited a large net export of nutrients and organic matter. Through the mariculture of shellfish and seaweeds, about $3.79 \pm 0.37 \mathrm{Mt} \mathrm{C} \mathrm{yr}^{-1}$ are consumed, and $1.20 \pm 0.11 \mathrm{Mt} \mathrm{C} \mathrm{yr}^{-1}$ are removed from coastal waters by harvesting (1999 to 2008) (Tang et al. 2011). Therefore, we propose the development of these 2 low-carbon and environmentally friendly culture systems in coastal eutrophic waters. However, due to the huge demand for food supplies, fish farming should not be totally rejected in spite of its negative effects on the coastal environment (especially in sheltered bays). Fish must be farmed offshore where the water is deep and hydrodynamics are strong. A macroalgal polyculture could also be adopted at fish farms to absorb excessive $\mathrm{N}$ and $\mathrm{P}$.

Acknowledgements. We thank Xiao-Ya Liu, Long-Kui Yao, Mei Yao, Zheng-Lai Gao, Hai-Na Zhang, Jun-Chao Mo for their cooperation in sample and environmental parameters analysis. We also thank 3 anonymous reviewers and the responsible editor Katherine Richardson for their insightful suggestions. This project was supported by the National Basic Research Program of China (2010CB428903), National Marine Public Welfare Research Project of China (200805069, 2012418013), Natural Science Foundation of Zhejiang Province (Y5110131, Y5100401), Innovative Team of Key Science and Technology on Marine Aquaculture of Zhejiang Province (2010R50025), and the Youth Science Foundation of SOA (2011106).

\section{LITERATURE CITED}

Alongi DM, Chong VC, Dixon P, Sasekumar A, Tirendi F (2003) The influence of fish cage aquaculture on pelagic carbon flow and water chemistry in tidally dominated mangrove estuaries of peninsular Malaysia. Mar Environ Res 55:313-333

An Z, Wang ZY, Li FM, Tian ZJ, Hu HY (2008) Allelopathic inhibition on red tide microalgae Skeletonema costatum by five macroalgal extracts. Front Environ Sci Eng China 2:297-305

Bricker SB, Longstaff B, Dennison W, Jones A, Boicourt K, Wicks C, Woerner J (2008) Effects of nutrient enrichment in the nation's estuaries: a decade of change. Harmful Algae 8:21-32

Brigolin D, Maschio GD, Rampazzo F, Giani M, Pastres R (2009) An individual-based population dynamic model for estimating biomass yield and nutrient fluxes through an off-shore mussel (Mytilus galloprovincialis) farm. Estuar Coast Shelf Sci 82:365-376

Casé M, Leca EE, Leitão SN, Anna EES, Schwamborn R, Junior ATM (2008) Plankton community as an indicator of water quality in tropical shrimp culture ponds. Mar
Pollut Bull 56:1343-1352

Coen LD, Brumbaugh RD, Bushek D, Grizzle R and others (2007) Ecosystem services related to oyster restoration. Mar Ecol Prog Ser 341:303-307

COYBEC (China Ocean Yearbook Editoring Committee) (2009) China ocean yearbook. China Ocean Press, Beijing

David CPC, Maria YYS, Siringan FP, Reotita JM and others (2009) Coastal pollution due to increasing nutrient flux in aquaculture sites. Environ Geol 58:447-454

Dong LX, Su JL (2000a) Salinity distribution and mixing in Xinagshanggang Bay I. Salinity distribution and circulation pattern. Oceanol Limnol Sin 31:151-158 (in Chinese)

Dong LX, Su JL (2000b) Salinity distribution and mixing in Xinagshanggang Bay II. Mixing analysis. Oceanol Limnol Sin 31:322-326 (in Chinese)

Dong QX, Lin JD, Shang X, Li J, Huang CJ (2008) Water, organic matter, nitrogen and phosphorus contents in sediment of a large-scale mariculture area in the Zhelin Bay of eastern Guangdong Province, China. Acta Oceanol Sin 27:133-148

> Dupuy C, Vaquer A, Lam-Höai T, Rougier C and others (2000) Feeding rate of the oyster Crassostrea gigas in a natural planktonic community of the Mediterranean Thau Lagoon. Mar Ecol Prog Ser 205:171-184

ECBCC (Editorial Committee of the Bay Chorography in China) (1992) The Bay Chorography in China, Part 5. Ocean Press, Beijing

FAO (2009) The state of world fisheries and aquaculture (SOFIA) 2008. FAO Fisheries Department, Rome

Fei XG (2004) Solving the coastal eutrophication problem by large scale seaweed cultivation. Hydrobiologia 512: 145-151

Fulford RS, Breitburg DL, Newell RIE, Kemp WM, Luckenbach M (2007) Effects of oyster population restoration strategies on phytoplankton biomass in Chesapeake Bay: a flexible modeling approach. Mar Ecol Prog Ser 336: 43-61

Grangeré K, Lefebvre S, Bacher C, Cugier P, Ménesguen A (2010) Modelling the spatial heterogeneity of ecological processes in an intertidal estuarine bay: dynamic interactions between bivalves and phytoplankton. Mar Ecol Prog Ser 415:141-158

Grzebyk D, Berland B (1996) Influences of temperature, salinity and irradiance on growth of Prorocentrum minimum (Dinophyceae) from the Mediterranean Sea. J Plankton Res 18:1837-1849

$>$ He PM, Xu SN, Zhang HY, Wen SS, Dai YJ, Lin SJ, Yarish C (2008) Bioremediation efficiency in the removal of dissolved inorganic nutrients by the red seaweed, Porphyra yezoensis, cultivated in the open sea. Water Res 42: 1281-1289

> Holmer M, Heilskov AC (2008) Distribution and bioturbation effects of the tropical alpheid shrimp Alpheus macellarius in sediments impacted by milkfish farming. Estuar Coast Shelf Sci 76:657-667

Hu WF, Lo W, Chua H, Sin SN, Yu PHF (2001) Nutrient release and sediment oxygen demand in a eutrophic landlocked embayment in Hong Kong. Environ Int 26: 369-375

> Huang CH, Lin HJ, Huang TC, Su HM, Hung JJ (2008) Responses of phytoplankton and periphyton to systemscale removal of oyster-culture racks from a eutrophic tropical lagoon. Mar Ecol Prog Ser 358:1-12

Hung JJ, Kuo F (2002) Temporal variability of carbon and 
nutrient budgets from a tropical lagoon in Chiku, southwestern Taiwan. Estuar Coast Shelf Sci 54:887-900

- Islam MS (2005) Nitrogen and phosphorus budget in coastal and marine cage aquaculture and impacts of effluent loading on ecosystem: review and analysis towards model development. Mar Pollut Bull 50:48-61

Lauer PR, Fernandes M, Fairweather PG, Tanner J, Cheshire A (2009) Benthic fluxes of nitrogen and phosphorus at southern bluefin tuna Thunnus maccoyii seacages. Mar Ecol Prog Ser 390:251-263

Lefebvre S, Leal JCM, Dubois S, Orvain F, Blin J, Bataillé M, Ourry A, Galois R (2009) Seasonal dynamics of trophic relationships among co-occurring suspension-feeders in two shellfish culture dominated ecosystems. Estuar Coast Shelf Res 82:415-425

Liao YB, Chen QZ, Zeng JN, Gao AG, Liu JJ, Jiang ZB (2008) Thermal effect on the marine phytoplankton in Xiangshan Bay. Acta Ecol Sin 28:4203-4212 (in Chinese)

Lü HQ, Chang KM, Shi GD (2009) Circulation and distribution of nitrogen and phosphorus in Xiangshan Bay, China. Oceanol Limnol Sin 40:138-144 (in Chinese)

Mao YZ, Zhou Y, Yang HS, Wang RC (2006) Seasonal variation in metabolism of cultured Pacific oyster, Crassostrea gigas, in Sanggou Bay, China. Aquaculture 253:322-333

Mazouni N, Gaertner JC, Deslous-Paoli JM (2001) Composition of biofouling communities on suspended oyster cultures: an in situ study of their interactions with the water column. Mar Ecol Prog Ser 214:93-102

- Navarro N, Leakey RJG, Black KD (2008) Effect of salmon cage aquaculture on the pelagic environment of temperate coastal waters: seasonal changes in nutrients and microbial community. Mar Ecol Prog Ser 361:47-58

> Neori A, Chopin T, Troell M, Buschmann AH and others (2004) Integrated aquaculture: rationale, evolution and state of the art emphasizing seaweed biofiltration in modern mariculture. Aquaculture 231:361-391

Newell RIE (2004) Ecosystem influences of natural and cultivated populations of suspension-feeding bivalve molluscs: a review. J Shellfish Res 23:51-61

> Newell RIE, Kemp WM, Hagy JD, Cerco CF, Testa JM, Boynton WR (2007) Top-down control of phytoplankton by oysters in Chesapeake Bay, USA: comment on Pomeroy et al. (2006). Mar Ecol Prog Ser 341:293-298

Ning XR, Hu XG (2002) Aquacultural ecology and carrying capacity assessment of fish cage in Xiangshan Bay. China Ocean Press, Beijing

> Nobre AM, Ferreira JG, Nunes JP, Yan XJ and others (2010) Assessment of coastal management options by means of multilayered ecosystem models. Estuar Coast Shelf Sci 87:43-62

Pedersen MF, Borum J (1996) Nutrient control of algal growth in estuarine waters: nutrient limitation and the importance of nitrogen requirements and nitrogen storage among phytoplankton and species of macroalgae. Mar Ecol Prog Ser 142:261-272

> Peterson CH, Grabowski JH, Powers SP (2003) Estimated enhancement of fish production resulting from restoring oyster reef habitat: quantitative valuation. Mar Ecol Prog Ser 264:249-264

> Pomeroy LR, D'Elia CF, Schaffner LC (2006) Limits to topdown control of phytoplankton by oysters in Cheasapeake Bay. Mar Ecol Prog Ser 325:301-309

Quan WM, Zhu JX, Ni Y, Shi LY, Chen YQ (2009) Faunal utilization of constructed intertidal oyster (Crassostrea rivularis) reef in the Yangtze River estuary, China. Ecol Eng
35:1466-1475

> Rodney WS, Paynter KT (2006) Comparisons of macrofaunal assemblages on restored and non-restored oyster reefs in mesohaline regions of Chesapeake Bay in Maryland. J Exp Mar Biol Ecol 335:39-51

San Diego-McGlone ML, Azanza RV, Villanoy CL, Jacinto GS (2008) Eutrophic waters, algal bloom and fish kill in fish farming areas in Bolinao, Pangasinan, Philippines. Mar Pollut Bull 57:295-301

> Sidik MJ, Rashed-Un-Nabi M, Hoque MA (2008) Distribution of phytoplankton community in relation to environmental parameters in cage culture area of Sepanggar Bay, Sabah, Malaysia. Estuar Coast Shelf Sci 80: 251-260

> Souchu P, Vaquer A, Collos Y, Landrein S, Deslous-Paoli JM, Bibent B (2001) Influence of shellfish farming activities on the biogeochemical composition of the water column in Thau lagoon. Mar Ecol Prog Ser 218:141-152

Takabayashi M, Lew K, Johnson A, Marchi AL, Dugdale R, Wilkerson FP (2006) The effect of nutrient availability and temperature on chain length of the diatom, Skeletonema costatum. J Plankton Res 28:831-840

Tallman JC, Forrester GE (2007) Oyster grow-out cages function as artificial reefs for temperate fishes. Trans Am Fish Soc 136:790-799

Tang Q, Zhang J, Fang J (2011) Shellfish and seaweed mariculture increase atmospheric $\mathrm{CO}_{2}$ absorption by coastal ecosystems. Mar Ecol Prog Ser 424:97-104

Taylor J, Bushek D (2008) Intertidal oyster reefs can persist and function in a temperate North American Atlantic estuary. Mar Ecol Prog Ser 361:301-306

ter Braak CJF, Smilauer P (2002) CANOCO reference manual and CanoDraw for Windows user's guide: software for canonical community ordination (version 4.5). Microcomputer Power, Ithaca, NY

- Thomsen MS, Silliman BR, Mcglathery KJ (2007) Spatial variation in recruitment of native and invasive sessile species onto oyster reefs in a temperate soft-bottom lagoon. Estuar Coast Shelf Sci 72:89-101

Trottet A, Roy S, Tamigneaux E, Lovejoy C, Tremblay R (2008a) Impact of suspended mussels (Mytilus edulis L.) on plankton communities in a Magdalen Islands lagoon (Québec, Canada): a mesocosm approach. J Exp Mar Biol Ecol 365:103-115

Trottet A, Roy S, Tamigneaux E, Lovejoy C, Tremblay R (2008b) Influence of suspended mussel farming on planktonic communities in Grande-Entrée Lagoon, Magdalen Islands (Québec, Canada). Aquaculture 276: 91-102

> Vezzulli L, Moreno M, Marin V, Pezzati E, Bartoli M, Fabiano M (2008) Organic waste impact of capture-based Atlantic bluefin tuna aquaculture at an exposed site in the Mediterranean Sea. Estuar Coast Shelf Sci 78: 369-384

> Wang ZH, Qi YZ, Chen JF, Xu N, Yang YF (2006) Phytoplankton abundance, community structure and nutrients in cultural areas of Daya Bay, South China Sea. J Mar Syst 62:85-94

- Wang Y, Yu ZM, Song XX, Tang XX, Zhang SD (2007) Effects of macroalgae Ulva pertusa (Chlorophyta) and Gracilaria lemaneiformis (Rhodophyta) on growth of four species of bloom-forming dinoflagellates. Aquat Bot 86: 139-147

Xiao YJ, Ferreira JG, Bricker SB, Nunes JP, Zhu MY, Zhang XL (2007) Trophic assessment in Chinese coastal sys- 
tems-review of methods and application to the Changjiang (Yangtze) Estuary and Jiaozhou Bay. Estuar Coast 60:901-908

Yan T, Zhou MJ, Qian PY (2002) Combined effects of temperature, irradiance and salinity on growth of diatom Skeletonema costatum. Chin J Oceanology Limnol 20: 237-243

Yang YF, Li CH, Nie XP, Tang DL, Chung IK (2004) Development of mariculture and its impacts in Chinese coastal waters. Rev Fish Biol Fish 14:1-10

Ye Y, Xu JL, Ying QL, Wei DY, Chen QZ, Ning XR (2002) Changes of nutrient in net aquaculture area of Xiang-

Editorial responsibility: Katherine Richardson, Copenhagen, Denmark shan Harbor. Mar Environ Sci 21:39-41 (in Chinese)

Yin K, Qian PY, Wu MCS, Chen JC, Huang L, Song X, Jian W (2001) Shift from P to N limitation of phytoplankton growth across the Pearl River estuarine plume during summer. Mar Ecol Prog Ser 221:17-28

You ZJ, Jiao HF (2011) Study on the ecology and environmental protect and restored technology of Xiangshan Bay. China Ocean Press, Beijing

Zhou Y, Yang H, Zhang T, Liu S and others (2006) Influence of filtering and biodeposition by the cultured scallop Chlamys farreri on benthic-pelagic coupling in a eutrophic bay in China. Mar Ecol Prog Ser 317:127-141

Submitted: June 15, 2011; Accepted: November 11, 2011 Proofs received from author(s): January 21, 2012 